\title{
Determination the role of risk factor in neonatal jaundice disease at AL- Nasiriya city
}

\author{
Mundther Kamil Al-sadawy \\ Community health Dept-Nassirya technical institute
}

\section{Abstract:}

Descriptive study was carried out to assess of neonatal jaundice in the sample consist of 150 patients selected from Bent - AL Huda hospital during ( 1- $10-2012$ ) to ( 1- 10 -2013). Neonatal jaundice measured by application of questioners that designed by researchers themselves collected through personal interview of patients family as mean of data collection through use statistically tool( frequent, percentage, X2 ) and through use in program SPSS- V15 to analysis data. The aim from the study is to determine risk factor of neonatal jaundice. The result revealed the incidence of neonatal jaundice more in the male, low birth weight, NVD, breast feed, mother did not receive Anti - D finally the main recommendation should be monitor after birth the neonate have risk factor of jaundice .

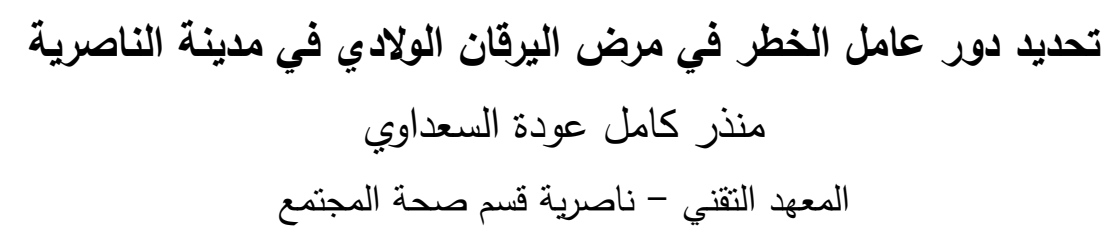

الخلاصة:

دراسة وصفية لتقيم اليرقان الولادي في عينة من ( 10 ) مريض تراوحت اعمارهم (من الولادة - مسنه ) تم اختيارهم من مستشفى بنت الهدى

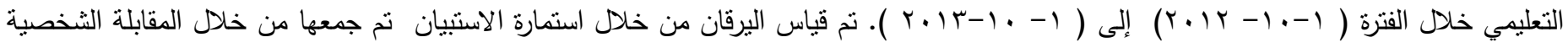

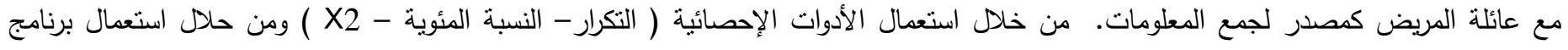
SPSS

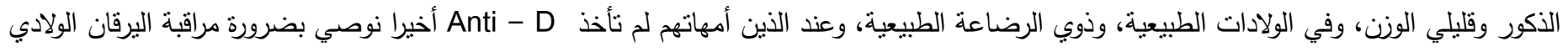

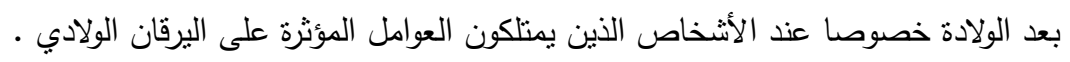

\section{Introduction:}

Jaundice in a common and, in most cases, benign problem in neonates, is observed during the 1st wk of life in approximately $60 \%$ of term infants and $80 \%$ of preterm infants in the world. The yellow color usually results from the accumulation of unconjugated, nonpolar, lipid - soluble bilirubin pigment in the skin. This unconjugated bilirubin (designated indirect acting by nature of the Van den Bergh reaction ) is an end product of hemi-protein catabolism from a series of enzymatic reactions by hemi- oxygenate and biliverdin reeducates and non - enzymatic reducing agents in the reticuloendothelial cells[1,2].Jaundice is usually detectable clinically when the plasma bilirubin exceeds $50 \mathrm{umol} / \mathrm{L}$ ( $3 \mathrm{mg} / \mathrm{dL}$ ). It may also be due to part to deposition of pigment from conjugated bilirubin, the end product from indirect, unconjugated bilirubin that 
has undergone conjugation in the liver cell micro some by the enzyme uredines diphosphoglucuronic acid ( UDP ) - glucuronyl.Transferase to from the polar , water- soluble glucuronide of bilirubin ( direct reacting ) $[3,4]$. Although bilirubin may have a physiologic role as an antioxidant, elevated levels of indirect, unconjugated bilirubin are potentially neurotoxic. Even though the conjugated form is not neurotoxic, direct hyperbilirubinemia indicates potentially serious hepatic disorders or systemic illnesses .During the neonatal period, metabolism of bilirubin is in transition from the fetal stage during which the placenta is the principal route of elimination of lipid - soluble, unconjugated bilirubin to the adult stage, during which the water soluble conjugated from is excreted from hepatic cells into the biliary system and gastrointestinal tract $[5,6,7]$. Unconjugated hyper bilirubinemia may be caused or increased by any factor that

1- Increases that load of bilirubin to be metabolized by the liver hemolytic anemia's, polycythemia, shortened red cell life as a result of immaturity or transfused cells , increased intrahepatic circulation, infection)

2-Damages or reduces the activity of the transferees enzyme or other related enzymes ( genetic deficiency, hypoxia, infection, thyroid deficiency .

3- Competes for or blocks the transfers enzyme (drugs and other substances requiring glucuronic acid conjugation [8]

4- Lead to an absence or decreased amounts of the enzyme or to reduction of bilirubin uptake by liver cells (genetic defect, and prematurity) . The toxic effects of elevated serum levels of unconjugated bilirubin are increased by factors that reduce the retention of bilirubin in the circulation hypoproteinemia, displacement of bilirubin from its binding sites on albumin by competitive binding of drug such as sulfisoxazole and moxalactam, acidosis , and increased free fatty acid concentration secondary to hypoglycemia starvation, on hypothermia ) [ 9,10,11].

Neurotoxic effects are directly not only to the permeability of the blood - brain barrier and nerve cell membranes but also to neuronal susceptibility to injury , early and frequent feeding decreases whereas breast feeding and dehydration increase serum levels of bilirubin . Delay in passage of meconium, which contains $1 \mathrm{mg}$ bilirubin / dL, may contribute to jaundice by enter hepatic circulation after DE conjugation by intestinal glucuronidase drugs such as oxytocin and chemicals used in the nursery such as phenolic detergents may also produce unconjugated hyperbilirubinemia . Risk factors for unconjugated hyperbilirubinemia are noted following. Additional risk factors include polycythemia, infection, prematurity, and being an infant of a diabetic mother.

\section{Types of jaundice:}

1- Physiologic jaundice (Icterus neonatorum):

Jaundice results when the liver cannot clear the blood of the pigment (bilirubin) that results from the breakdown of $\mathrm{Hb}$ from destroyed RBCs. Under normal circumstances, the level of indirect - reacting bilirubin in umbilical cord serum is $1-3 \mathrm{mg} / \mathrm{dL}$ and rises at a rate of $<5 \mathrm{mg} / \mathrm{dL} 24 \mathrm{hr}$; thus, jaundice becomes visible on the 2nd-3rd day, usually peaking between the 2nd and 4th days at 5- $6 \mathrm{mg} / \mathrm{dLand}$ decreasing to below 2 $\mathrm{mg} / \mathrm{dL}$ between the 5th and 7th days of life [12]. Jaundice associated with these changes is designated physiologic and is believed to the results of increased bilirubin production from the breakdown of fetal red blood cells combined with transient limitation in the conjugation of bilirubin by the immature neonatal liver. Frequently, the terms exaggerated physiologic jaundice and hyperbilirubinemia of the newborn are used for infants whose primary problem is probably a deficiency or inactivity of bilirubin glucuronyl transferees (Gilbert syndrome) rather than an excessive load of bilirubin for excretion. The combination of glucose $-6-$ phosphate dehydrogenase (G6PD) deficiency and mutation of the promoter region of UDP-glucuronyl nonphsiologic hyper bilirubin may also be caused by mutations in the gene for bilirubin UDP-glucuronyl transferees.

2- Risk factor of exaggerated physiologic jaundice:

Preterm infants and in the presence of asphyxia, intraventricular hemorrhage, hemolysis or drugs that displace bilirubin from albumin [13].

\section{3-Jaundice associated with breast - feeding:}

Significant elevation unconjugated bilirubin ( breast -milk jaundice ) develops in an estimated $2 \%$ of breast -fed term infant after the 7th day of life or presents typically in the second week of life, with maximal concentrations as high as $10-30 \mathrm{mg} / \mathrm{dL}$ reaching during the 2 nd- 3 rd week. If nursing is discontinued, the serum bilirubin level falls rapidly, reaching normal levels within a few day. With resumption of breast - feeding bilirubin levels seldom return to previously high levels. Phototherapy may be of benefit. Although uncommon, kernicterus can occur in patients with breast - milk jaundice .The etiology of breast - milk jaundice is not entirely clear, but may be attributed to the 
1- Presence of glucuronidase in some breast milk.

2-Inadequate intake of milk and calories with or without relative dehydration leading to increased intestinal bilirubin absorption and enter hepatic circulation.

3-Factors found in the milk of some mothers of infants with BMJ include:

A-Pregnanediol isomer: Steroid metabolite of progesterone, competitive inhibitor of hepatic gluronyl transferees.

B-Increased concentration of no esterified (free fatty acids that inhibit hepatic glucronyl transferees) .

C-Factors that increase enter hepatic circulation of bilirubin.

D-Also defects in bilirubin uredines diphosphateglucuronosyl transferees gene UGTAI) may be associated with BM2. [ 14 ]

\section{Aims:}

1-To determine risk factor of neonatal jaundice.

2-To early diagnosis and treatment to avoid serious complication of hyperbilirubinemia .

\section{Materials and Methods:}

The study was conducted at the hospital of hospital it Bent -AL Huda this hospital receives neonates who have a jaundice. The data when collected with constructed questionnaire, through an application of direct interview as mean of data collection. Data analyzed through application of two different approaches as follows:

*Descriptive statistical data analysis approach which include (frequency, percentage)

*Inferential (X2 test).

\section{Results:}

Table ( 1 ): Showed that the highest percentage of the incidence of neonatal jaundice in the male more than female. The highest percentage ( $56 \%$ was noticed in the male . while the lowest percentage of incidence of neonatal jaundice ( $44 \%$ ) was noticed in the female.

Table ( 1 ) Sex demographic characteristic of the sample

\begin{tabular}{|lccc|}
\hline Sex & Number & Percentage & Total \\
\hline Male & 84 & $56 \%$ & 84 \\
Female & 66 & $44 \%$ & 66 \\
Total & 150 & $100 \%$ & 150 \\
\hline
\end{tabular}

Table (2) : This table showed the incidence of neonatal jaundice the highest percentage $(50,6 \%)$ in the preterm. While the lowest of incidence of neonatal jaundice $(17,4 \%)$ in the post term .

Table ( 2 ) : Distribution of studied sample according gestational age

\begin{tabular}{lccc}
\hline Gestational age & Number & Percentage & Total \\
\hline Preterm & 76 & $50 \%$ & 76 \\
Term & 48 & $32 \%$ & 48 \\
Post term & 26 & $17 \%$ & 26 \\
Total & 150 & $100 \%$ & 150
\end{tabular}

Table ( 3 ) : Revealed the TSB in the underweight neonate from $(5-15) \mathrm{mg} / \mathrm{dL}$ had ( 46 neonate ) and its show the TSB in the normal from $(15-25) \mathrm{mg} /$ dL had ( 13 neonate) .

Table ( 3 ) : Association weight with TSB at admission

\begin{tabular}{|c|c|c|c|c|c|c|c|c|c|c|c|}
\hline \multirow[t]{4}{*}{ Weight } & \multicolumn{10}{|c|}{ TSB at admission } & \multirow[t]{4}{*}{ Total } \\
\hline & \multirow{2}{*}{\multicolumn{2}{|c|}{$\begin{array}{l}\text { From } \\
1 \text { to5 } \mathrm{mg} / \mathrm{dL}\end{array}$}} & \multirow{2}{*}{\multicolumn{2}{|c|}{$\begin{array}{l}\text { From } \\
5.1 \text { to } 10 \mathrm{mg} / \mathrm{d} \\
\text { L }\end{array}$}} & \multirow{2}{*}{\multicolumn{2}{|c|}{$\begin{array}{l}\text { From } \\
10.1 \text { to } 15 \mathrm{mg} / \mathrm{dL}\end{array}$}} & \multirow{2}{*}{\multicolumn{2}{|c|}{$\begin{array}{l}\text { From } \\
15.1 \text { to } 20 \mathrm{mg} / \mathrm{d} \\
\mathrm{L}\end{array}$}} & \multirow{2}{*}{\multicolumn{2}{|c|}{$\begin{array}{l}\text { From 20.1 } \\
\text { To25mg/d } \\
\text { L }\end{array}$}} & \\
\hline & & & & & & & & & & & \\
\hline & No & $\%$ & No & $\%$ & No & $\%$ & No & $\%$ & No & $\%$ & \\
\hline $\begin{array}{l}\text { Under } \\
\text { weight }\end{array}$ & 3 & 3.8 & 22 & 28.5 & 23 & 29.8 & 18 & 23.3 & 11 & 14.2 & 77 \\
\hline $\begin{array}{l}\text { Normal } \\
\text { weight }\end{array}$ & 0 & 0 & 16 & 33.3 & 17 & 35.4 & 11 & 22.9 & 4 & 8.3 & 48 \\
\hline $\begin{array}{l}\text { Over } \\
\text { weight }\end{array}$ & 2 & 8 & 6 & 24 & 12 & 48 & 4 & 16 & 1 & 4 & 25 \\
\hline Total & 5 & 3.3 & 44 & 29.3 & 52 & 34.6 & 33 & 22 & 16 & 10.6 & 150 \\
\hline
\end{tabular}

Table (4): This table showed the incidence of neonatal jaundice in the mother have $\mathrm{RH}-$ and $\mathrm{O}+$ more than other blood group.

Table ( 4 ) : Distribution of studied sample according blood group of the mother

\begin{tabular}{lccc}
\hline Blood group of mother & Number & Percentage & Total \\
\hline O+ group and RH- & 116 & $77.3 \%$ & 116 \\
Other blood group & 34 & $22.7 \%$ & 34 \\
Total & 150 & $100 \%$ & 150 \\
\hline
\end{tabular}

Table (5): This table showed the incidence of neonatal jaundice the highest percentage $(42 \%)$ in the breast 
feeding. While the lowest percentage $(28 \%)$ in the bottle feeding.

Table (5 ) : Distribution of studied sample according type of feeding

\begin{tabular}{llll}
\hline Type of feeding & Number & percentage & Total \\
\hline Bottle & 42 & $28 \%$ & 42 \\
Breast & 64 & $42.6 \%$ & 64 \\
Mixed & 44 & $29.4 \%$ & 44 \\
Total & 150 & $100 \%$ & 150 \\
\hline
\end{tabular}

Table (6): Showed this table the incidence of neonatal jaundice the highest percentage $(58 \%)$ in the NVD more than $\mathrm{C} / \mathrm{S}$.

Table ( 6 ) : Distribution of studied sample according type of delivery .

\begin{tabular}{lccc}
\hline Type of delivery & Number & Percentage & Total \\
\hline NVD & 88 & $58.6 \%$ & 88 \\
\hline C/S & 62 & $41.4 \%$ & 62 \\
Total & 150 & $100 \%$ & 150 \\
\hline
\end{tabular}

Table (7): This table showed the incidence of neonatal jaundice the highest percentage $(69 \%)$ in women did not receive anti $\mathrm{D}$. While the lowest percentage $(30.7 \%$ ) in the women received anti D .

Table ( 7 ) : Distribution of studied sample according anti-D

\begin{tabular}{|lccc|}
\hline Anti - D & Number & Percentage & Total \\
\hline Women received Anti - D & 16 & $30.7 \%$ & 16 \\
\hline Women did not received Anti-D & 36 & $69.3 \%$ & 36 \\
\hline $\begin{array}{l}\text { Total number of women needed } \\
\text { anti - D }\end{array}$ & 52 & $100 \%$ & 52 \\
\hline
\end{tabular}

Table ( 8 ): This table showed the highest percentage ( $64 \%$ ) in the phototherapy. While the lowest percentage ( $36 \%)$ in exchange of blood and phototherapy .
Table ( 8 ) : Distribution of studied sample according of type of treatment

\begin{tabular}{lccc}
\hline Type of treatment & Number & Percentage & Total \\
\hline Phototherapy & 96 & $64 \%$ & 96 \\
$\begin{array}{l}\text { Exchange of blood and } \\
\text { Phototherapy }\end{array}$ & 54 & $36 \%$ & 54 \\
Total & 150 & $100 \%$ & 150 \\
\hline
\end{tabular}

\section{Discussion:}

Our study shows the incidence of neonatal jaundice in the male more than female (in table 1 ). Table 2 ( Gestational age ) and table 3 ( association weight with TSB at admission ) revealed similarity between preterm and underweight in the total ( $77 \%$ ) due to show the signs in preterm and underweight neonate more than term and normal weight. Table 4 ( blood group of mother ) showed the incidence of neonatal jaundice in the mother have $\mathrm{RH}-$ and $\mathrm{O}+$ more than blood group.

Table ( 5 ): This table showed the incidence of neonatal jaundice the highest percentage (69\%) in women did not receive anti $D$. While the lowest percentage ( $30.7 \%$ ) in the women received anti D . Table 6 showed the incidence of neonatal jaundice in the NVD more than C/S this agree 5- minute pediatric consult 4th edition ( Significance in the birth prolonged rupture of amniotic membranes, traumatic delivery, including the use of instruments such as forceps or vacuum, medication use ( e.g oxytocin ) are associated with jaundice ). Table 7( anti D ) showed the incidence of neonatal jaundice in the women did not receive anti D more than women received D. Table 8 (b type of treatment) the neonates that treat by the phototherapy are more than exchange of blood due to (the use of phototherapy has decreased the need for exchange transfusion in the term and preterm infants with hemolytic jaundice) Nelson pediatric 18 Edition page 102,3 . Exchange of blood in the study due to some factor: underweight, mother did not received anti D, preterm, RH- , NVD and TSB more than $18 \mathrm{mg} / \mathrm{dL}$. [15]

\section{Conclusion:}

The incidence of neonatal jaundice in the women did not receive anti D more than women received anti D . The incidence of neonatal jaundice in the mother RH- 
and $\mathrm{O}+$ more than other blood group, the incidence of neonatal jaundice in the normal vaginal delivery more than $\mathrm{C} / \mathrm{S}$ and the neonatal jaundice treated by phototherapy more than exchange of blood .

\section{Recommendation:}

1- Should be avoiding oxytocin over dose and stress during labor to prevent risk factor of jaundice.

2-Monitor the newborns after birth and should be monitor the neonate have risk factor of jaundice.

3-The mother should be receive anti- D if $\mathrm{RH}$ - after pregnant and abortion.

4- Teach the mother to feed the infant with breast at least $10-12$ times / day.

\section{$\underline{\text { References: }}$}

1-Dennery PA, Seidman DK: Neonatal hyperbilirubinemia. N Engl J Med 2001.

2-AAP Subcommittee on Hyperbilirubinemia: Management of hyperbilirubinemia in the newborn infant 35 or more weeks of gestation. Pediatrics 2004.

3 -Kernicterus in otherwise healthy, breast - fed term newborns. Pediatrics 2001

4-Kernicterus in full- term- United States , 1994- 1998. MMWR Morb Mortal Wkly Rep 2003.

5-Kernicterus in otherwise healthy, breast - fed term newborns . Pediatrics 1998 .

6-Hannam et al. 2002. Hannam S, McDonnell M, Rennie JM : Investigation of prolonged neonatal jaundice . Acta Paediatr 2002.

7-Johnson , 2004 . Johnson LH: System - based approach to management of neonatal jaundice and prevention of Kernicterus . J Pediatr 2004 .

8- Dennery PA, Seidman DK : Neonatal hyperbilirubinemia . N Engl J Med 2003.

9-Masisels and Kring, 2008 . Maisels MJ, Kring E : The contribution of hemolysis to early jaundice in normal newborns . Pediatrics 2008 .

10-Marouo et al; 2000. Maruo Y, Nishizawa K, Sato $\mathrm{H}$, et al: Association of neonatal hyperbilirubinemia with bilirubin UDPglucuronosyltrasferase polymorphism . Pediatrics 2000.

11-Monaghan et al ; 2001 . Monaghan G , Ryan M , Seddon $\mathrm{R}$, et al : Genetic variation in bilirubin UDP-glucronosyltransferase gene promoter and Gilbert,s syndrome . Lancet 2001 .
12-Oh et al ; 2006 . Oh W, Tyson JE, Fanaroff AA, et al : Association between peak serum bilirubin and neurodevelopmental outcomes in extremely low birth weight infant . Pediatrics 2006 .

13-Wennberg et al ; 2009 . Wennberg RP, Ahlfors CE, Bhutani VD, et al : Toward understanding kernicterus: a challenge to improve the management of jaundice newborns . Pediatrics 2009.

14-Moira $\mathrm{CH}$, Lawther $\mathrm{PJ}$ and Val Craham. : a challenge to improve the management of jaundice newborns . Pediatrics 2011.

15- Sherwood P, Waldron AH and Davies RJ . Peak flow records in diagnosis of neonatal jaundice. 2006 